\title{
Development of an Optimized Digital E-Recruitment Model for Sindh Police
}

\author{
Abdullah Maitlo ${ }^{1}$,Siraj Ahmed Solangi ${ }^{1}$, Yasir Ali Solangi ${ }^{1}$, Zulfiqar Ali Solangi $^{3}$, Inayatullah Soomro ${ }^{2}$, \\ Haque Nawaz ${ }^{4}$ \\ ${ }^{1}$ Department of Computer Science, Shah Abdul Latif University Khairpur, Pakistan, abdullah.maitlo@salu.edu.pk, \\ siraj.engineer@gmail.com, yasir_solangi@yahoo.com \\ ${ }^{2}$ Department of Mathematics, Shah Abdul Latif University Khairpur, Pakistan, inayat.soomro@ salu.edu.pk \\ ${ }^{3}$ Jubail Technical Institute, Education Sector Royal Commission Jubail Saudi Arabia, zulfs@ hotmail.com \\ ${ }^{4}$ Department of Computer Science, Sindh Madressatul Islam University, Karachi, Pakistan, \\ Corresponding author: hnlashari@smiu.edu.pk
}

\begin{abstract}
Information and communication technology (ICT) have profound influence in the modern world such that it has taken every sphere of life today. The advent of ICT has made the all activities relating to human and material resources utilize unto optimum level and making every aspect of life easier. In these days, the use of latest ICT technology like digital finger print identification, surveillance camera, and radio frequency identification devices ensure transparency and identity fraud. However, existing manual recruitment process in Sindh Police of Pakistan has been disputed at various platforms to ensure transparency. There have been several issues such as physical document identification and verification, physical tests, such as, running, jumping, obstacles overpassing, finger prints need to be transparent and apparent to respective authorities and aspirants during the recruitment process. Therefore, the purpose of this research article is to identify existing issues in current recruitment process. It provides appropriate solutions for fare recruitment process in Sindh Police Pakistan. This research is intended to Development of an Optimized Digital ERecruitment Model of Sindh Police for Sindh Police connected to National Database \& Registration Authority (NADARA) of Pakistan to verify aspirants' identity online, monitor their physical tests using RFID, surveillance cameras, GPS enabled bracelets generating automated digital reports of all aspirants, ensuring transparency and fairness in recruitment system of Sindh Police of Pakistan.
\end{abstract}

Keywords: Biometric, E-Recruitment, Information and communication technology, Sindh Police

\section{INTRODUCTION}

Sindh Police of Pakistan (SPP) has recruitment procedures for police service department which consists of several conventional physical inspections and substantiation of candidates. Due to increased population in Sindh province of Pakistan, it is a challenging for the department to conduct physical tests and maintain transparency in the whole recruitment process.

As a result, recruitment department miscarries the suitable candidates and inadequate people are chosen, hence they don't play out their responsibilities well indeed recruited for the specific positions announced. Every year Sindh Police receives huge number of applicants for various category jobs in the department and faces several problems of impersonation in physical exams, crowd management, continuous surveillance of running test, and verification of documents etc. Accordingly, it needs smart digital recruitment system to ensure transparency and swift recruitment procedure[1].

Therefore, the purpose of this research project is to propose for "Development of an optimized digital Erecruitment model of Sindh Police". The proposed model will incorporate an RFID, smart tagging, and biometric system linked with all concerned departments and government agencies for verification of aspirants' IDs and documents ensuring fair and transparent results. In which all means of the recruitment framework are put away in a shared information base. In the initial step framework recognizes the residency (Domicile) of competitor through the NADRA government agency of Pakistan if the candidate is having a place with specific residency that $\mathrm{He} / \mathrm{she}$ will get a remarkable electronic 
Identity (ID) created by the framework, and afterwards ahead for additional cycle.

At that point, all the particulars are put away in the framework, an RFID label will be created for every candidate, at that point candidate leads to the physical exam test such as running, jogging, jumping etc. the proposed model will gauge time and use surveillance cameras to focus proper speed and distance covered in kilometers.Having completed physical tests successful candidates will be put away in the information base and assigned other unique IDs for further academic tests. Further sections are discussed in this research article.

\section{BACKGROUND}

The employ recruitment is the essential procedure of finding and recruiting the appropriate and most profoundly qualified candidate for a particular category in public and private sector in swift and cost-effective way[2]. It can likewise be depicted as the way toward perusing for potential workers, motivating and urging them to go after positions. It is cycle, that starts with identification of the needs of the workplace concerning the action, and finishes with the selection of right person for the right job in an organization.

The existing recruitment system, which involves manual steps, is very expensive and it takes too much time for recruitment and selection process in different departments of Sindh Police of Pakistan (SPP) and other federally administrated regions of Pakistan as well. In this manually held system, the public and private sector announce employment advertisement in national or regional news media by paying a high cost. After following the published policy and procedure of application, the aspirants submit their job applications along with supporting, required educational, and experience credentials[3]. Once all job applications are received by the recruitment agency, the human resource department starts process of scrutiny manually which takes longer to issue the final list of eligible applicants for next stage of prewritten examination. Having passed written examination, the most suitable aspirants are selected for interview [4].

Several allied research studies have been conducted to approach same problem such as [5] presented the use of RFID technology identifying person identity and credentials to combat the impersonation in police department of South Africa. Same research is applied in Indian Police department for transparent and quick recruitment [6].
S.L Ting [7] has recommended the use of RFID is important for transparent recruitment. This research has also proposed the use of RFID and smart tagging system to support digital framework of e-recruitment in Sindh Police Pakistan.

\section{RESEARCH Methodology}

This research study is to propose digital e-recruitment system for Sindh Police of Pakistan. In order to suggest and understand the actual problems faced by Sindh Police of Pakistan in recruitment procedure, this research study consumed qualitative approach to conduct semi-structured interviews with concerned authorities from head of district police officers Superintendent of Police (SP) level and relevant recruitment, selection and training teams of Sindh Police and reviewed several previous reports on recruitment challenges faced by Sindh Police of Pakistan. The interview questions were highly focused on research topic and all participants were informed and ensured about the voice recording and keeping data confidential to be used for academic purpose only.

Henceforth, a proper digitization framework was proposed to improve the overall manual recruitment system into e-recruitment system. According to Robert K. Yin [8] initial, the author recorded openended face-to-face interviews and then write out the audio by utilizing qualitative data analysis tools.

This research employed research instrument as onetime study with total 15 number of interview participants, which involved all top management personnel. The purpose of the semi-structured interviews was to understand and analyse the recruitment issues of Sindh Police department during the recruitment of police officers and police soldiers such as, job application data processing, applicants' scrutiny process, applicant's physical examination running, jumping, push-ups, fronting and clarifying obstacles etc.

The semi-structured interviews were conducted for Sindh Police employees of Khairpur, Tando Mohammad Khan, and Sukkur districts. The response was collected based on 05 blocks/themes. The total number of participants were 15 and valid response was 10 out of 15 personnel.

\section{DEVELOPMENT OF E-RECRUITMENT MODEL}

The digital recruitment developed model for Sindh Police enable to store the electronic based centralized data of Sindh Police recruitment team for any time 
access with the help of internet connectivity. This briefly explains the conceptual proposed model and its features. The proposed recruitment model for erecruitment in Sindh Police of Pakistan is constructed on modifying the existing e-recruitment model of Prakash Yadao \& Simta [9]. Proposed digital model is very cost-effective to implement, digital supporting automated reports, online biometric verification, and documents verification of aspirants, digital monitoring of physical tests using RFID smart tags, digital storage and backup of data records for future evidence and secure.

The computerized recruitment model is easy to use graphical interface for recruitment agency to store and access the records of candidate at any divisional/sub divisional office of the Sindh Police of
Pakistan for data sharing every division/region electronically.

The advancement of an upgraded computerized erecruitment model for Sindh Police officials is made up as mix of equipment based on RFID smart tag and programming based connectivity of candidate to centralized server.

In this proposed model, the most problematic part of recruitment process which is physical tests (running, jumping, overpassing obstacles, monitoring) is controlled using microcontrollers and smart RFID detecting gadgets. The proposed e-recruitment model alludes to the way toward recognizing and appealing job seekers so as construct a pool of qualified candidates. As shown in Figure 1.

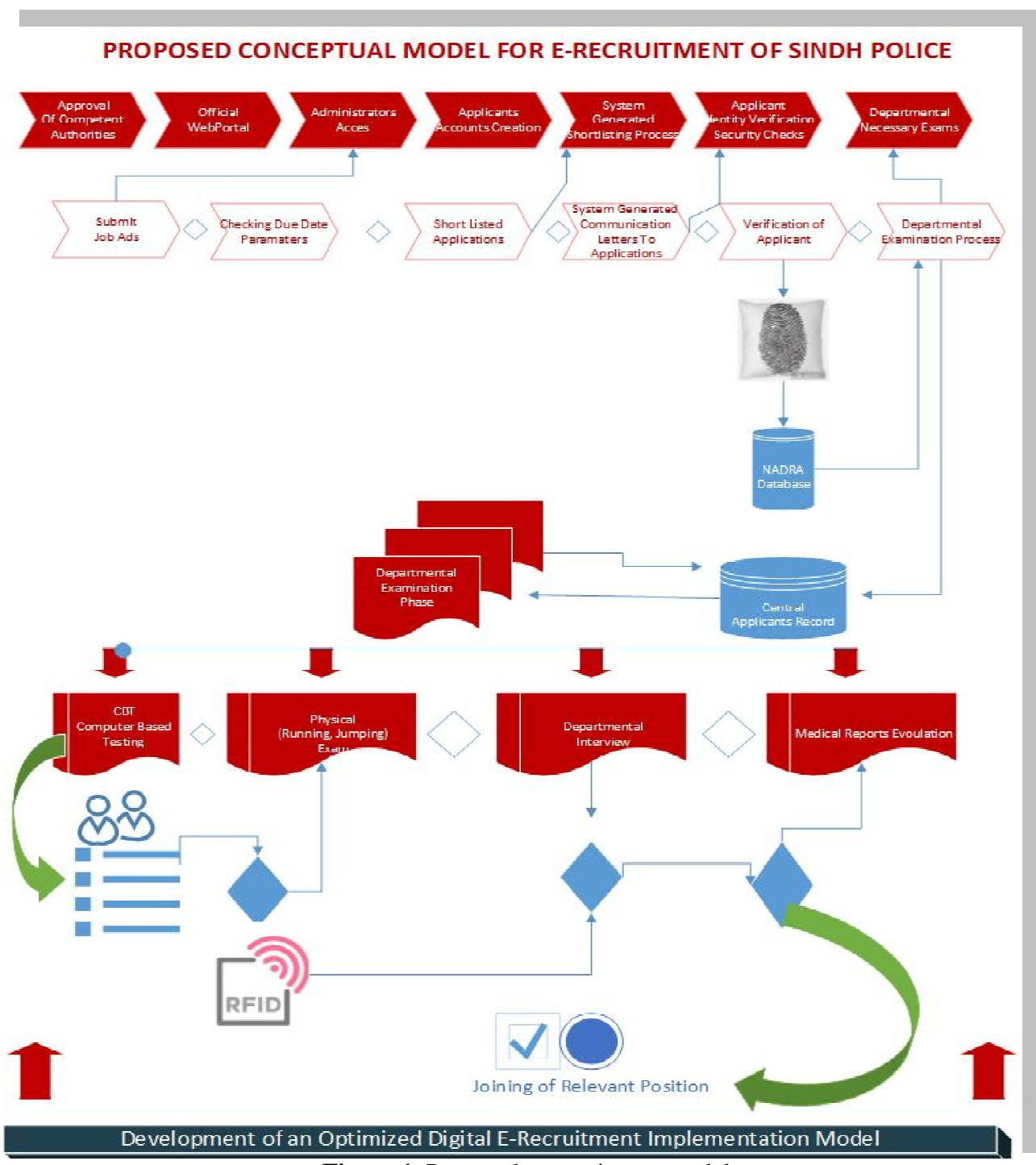

Figure 1. Proposed e-recruitment model 


\section{Features of E-Recruitment Model}

The digital e-recruitment model is user friendly graphical interface for recruitment Sindh Police personnel to store and access the records of applicant at any divisional/ sub divisional office of the Sindh Police department for information sharing each division/district electronically. The development of an optimized digital e-recruitment model for Sindh Police department is made up as combination of hardware-based RFID antenna and software-based applicant's data centre system.

In this research project the core part of aspirant physical examination/ running tracking \& monitoring system is RFID based microcontrollers and RFID sensing devices. The proposed e-recruitment model refers to the process of identifying and attracting job seekers so as build a pool of qualified job applicants.

The process comprises seven related stages; (a) approval of competent authorities, (b) official web portal announcement, (c) administrator access, (d) applicant accounts creation, (e) system generated shorting process, (f) applicants' identity verification security and checks, (g) departmental necessary exams. These all related seven stages are grouped into four phases.

\subsection{Recruitment Planning}

The first stage in the recruitment process is planning. Planning involves the number of job vacancies and information about the nature of these jobs into a set of objectives or targets that specify number, and type of applicants to be contacted, approval of authorities, and official announcement.

\subsection{Online Application Data Processing}

The ideal recruitment program is the one that attracts a relatively larger number of qualified applicants who will survive the screening process and accept positions with the Sindh Police department, when offered. Recruitment programs can miss the ideal in many ways: by failing to attract an adequate applicant pool, by under/over selling the firm, or by inadequately screening applicants before they enter the selection process. Thus, approaching the ideal individuals responsible for the recruitment process must know how many and what types of applicants are needed. Where and how to look for applicants with the appropriate qualifications and physical and health requirements, what inducements to use or avoid for various types of applicant groups, how to distinguish applicants who are unqualified from those who have a reasonable chance of success, and how to evaluate their physical and mental abilities.

\subsection{Applicant Identification by using Biometrics Verification}

The second decision in strategy development relates to the methods used in recruitment and selection. This decision is mainly influenced by the available technology. The advent of computers has made it possible for employers to scan national and international applicant qualifications. Although impersonal, computers have given employers and job applicants a wider scope of options in the initial screening stage. Technological advancement has made it possible for job applicants to gain better access. They have begun sending videotapes about themselves to a number of companies without wasting time and without spending money on travel.

\subsection{Applicant Physical / Running Tracking System}

The proposed research model suggests the most effective Applicant Tracking System, Digital geo tracking and video interviewing platform during the physical examination of applicants like running, push-ups and jumping etc. Adopting the proposed model helps Sindh Police department find high calibre candidates, deliver a superb candidate experience, reduce cost and time taken to hire talent, whilst freeing up valuable recruiting staff time.

\subsection{Online Application Data Processing}

The online job application data processing is the feature of development of an optimized digital e-recruitment model, which represent the actual candidate's data see figure 2 . Whenever Sindh Police department announce jobs opportunities it will display on official web portal of Sindh Police smart recruitment system, the applicant creates once time account by using internet and store data by self also attached relevant documents in shape of pdf (portable document format) and account profile user picture. After that the smart recruitment system of Sindh Police check primitive conditions for short listing processing these conditions may be age counting, verification of domicile, verification of residency and police verification record either applicant is not any criminal record. 


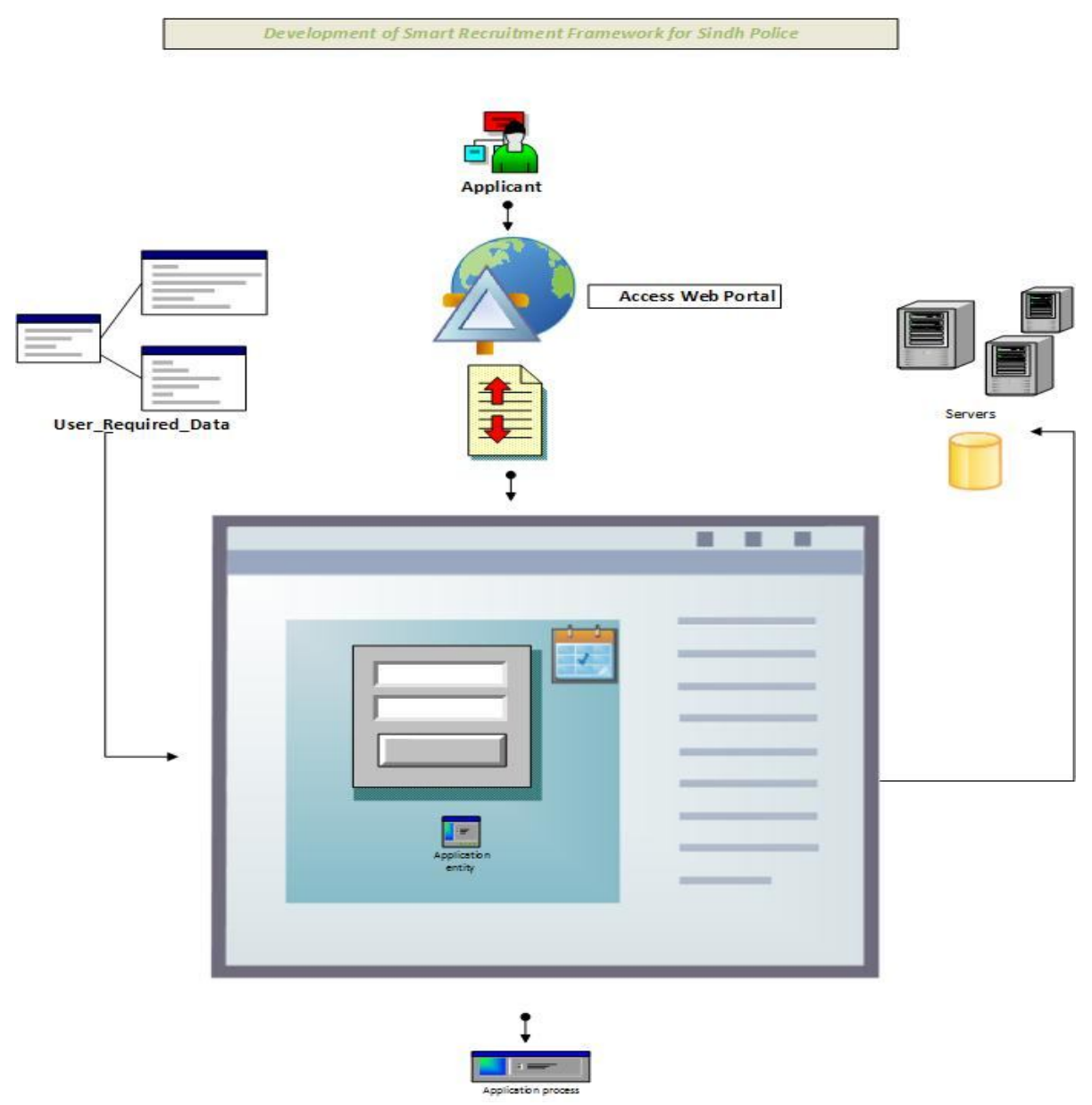

Figure 2. Online Applicant Data processing

\subsection{Applicant Identification by using Biometrics Verification}

Figure 3 describes the process of candidates' identification using biometrics method. The applicant identification feature is one of the latest and enhancement in proposed model for recruitment system, which is very beneficial for security purpose, according to interviewee participations applicant identity is the top most issue in Sindh Police recruitment process, no one can identify during the fake CNIC information, or anyone candidate may appear in the examination centre for performing another person's examination by using tempered CNIC. 


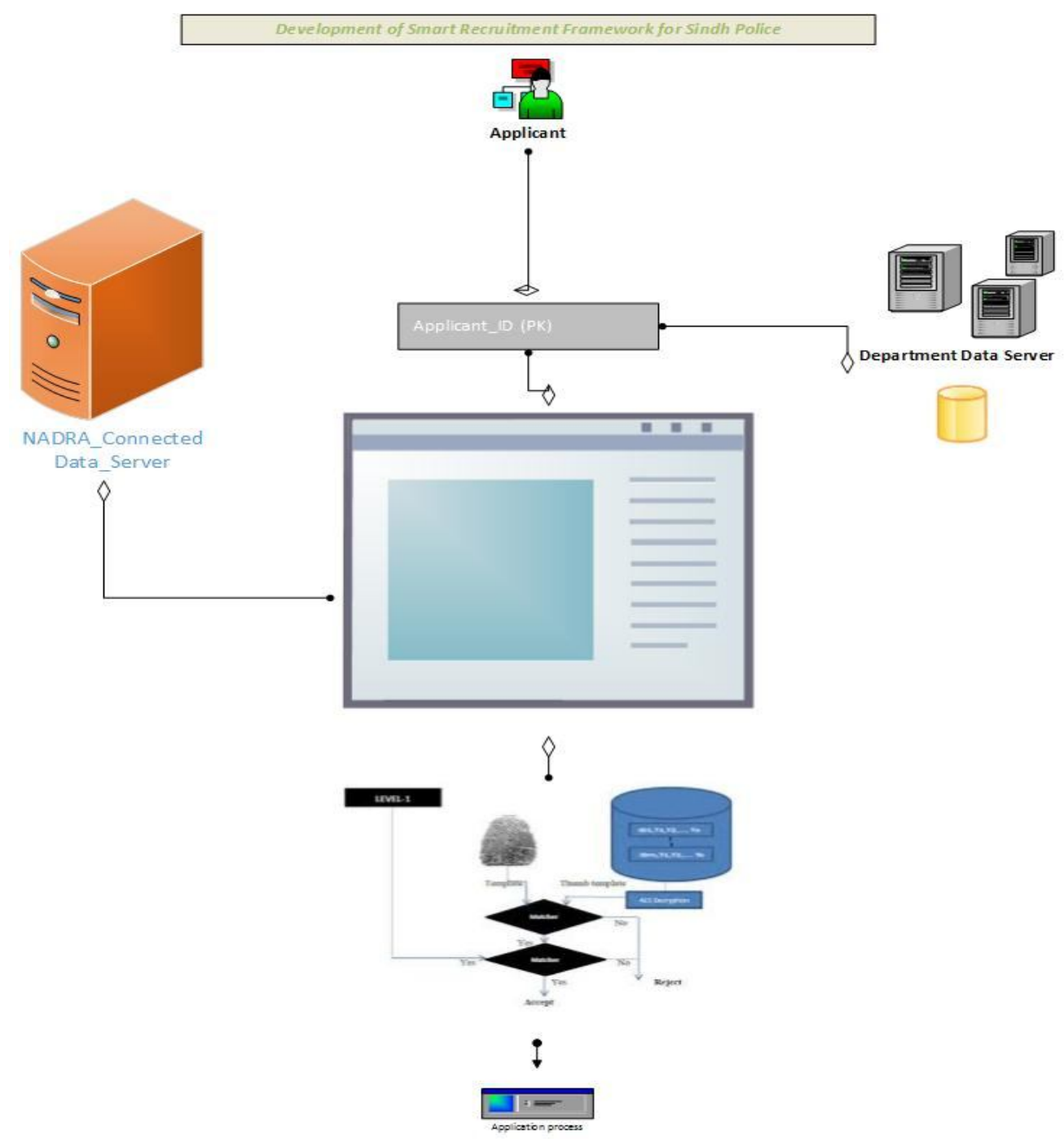

Figure 3. Applicant Identification/verification of biometrics

\subsection{Applicant Physical / Running Tracking System}

This feature of proposed model is based on RFID technology in this feature of developed model author suggested that how Sindh Police track candidate physical running, jumping and push-ups also system will store the candidate recoded data for future evidence, after that if anyone candidate could not qualify the running examination, he/she not blamed on police personnel see figure 4. 


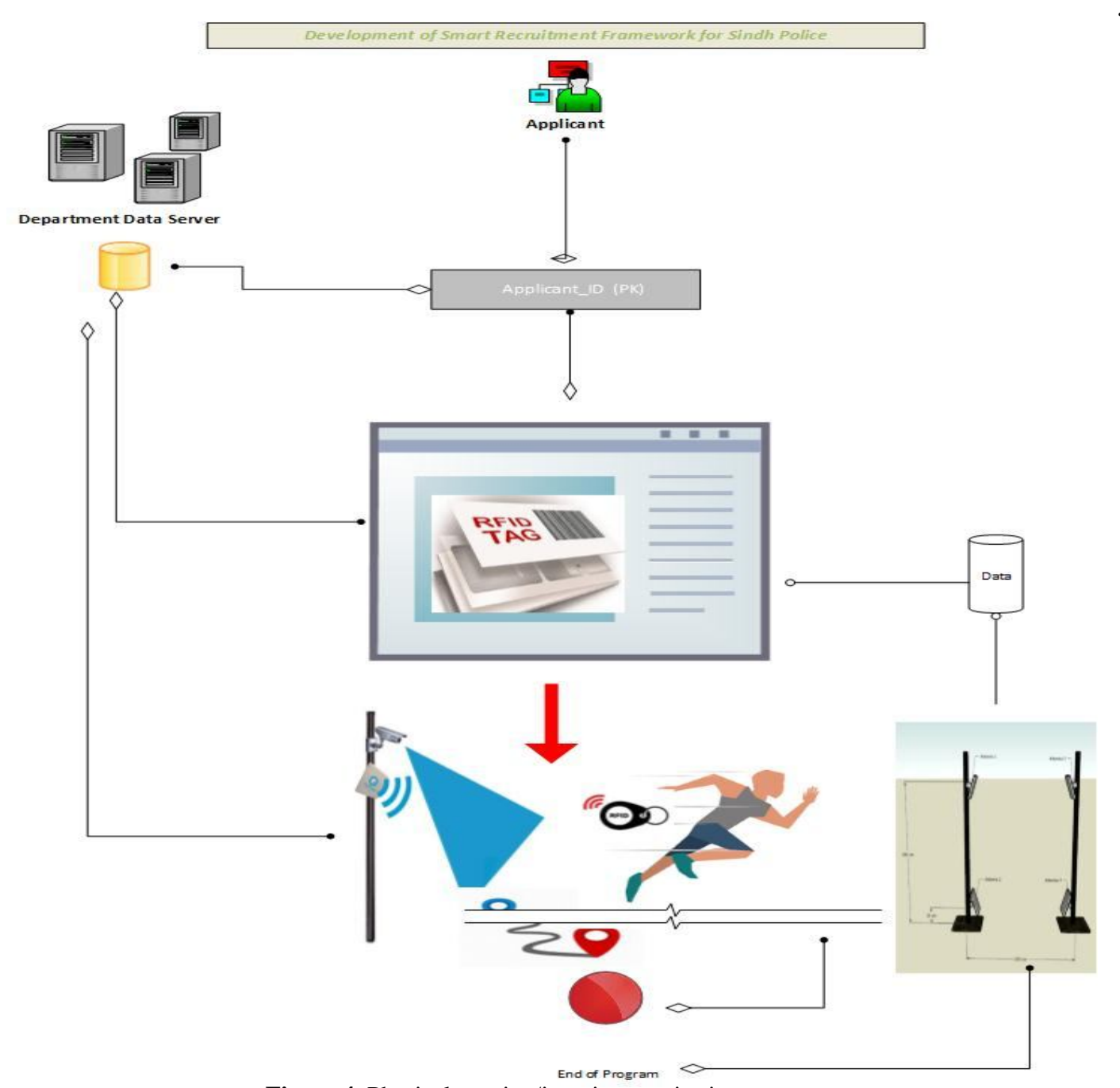

Figure 4. Physical running/jumping monitoring system

\section{Data Analysis \&Findings}

\subsection{Population and Data Sample}

According toDr. Sue Greener [10] a population is group of people, public/private organizational employees , public/private hospitals and instituations employees and academics students. In this research the population was total fifteen officials participated in data sample, face on face interviews of concerned officers were conducted then the author moved on next interviewee in same format, this cycle was repeated until the research data sampling size of fifteen was collected group of police department officers. The author used grounded based theorital sampling of semi-structued interviews format for collecting data from top management of Sindh Police department for different three districts. The inverviews were recoded the audios of participants with the approval of an official guide and departmental permission by senior police officials of Khairpur, Sukkur and Tando Mohammad Khan districts see table 1. 
Table 1. Population criterion of participents

\begin{tabular}{|c|c|}
\hline Population Criterion & Explanation \\
\hline Element & It is unit analysis to collect data from Sindh Police officers \\
\hline 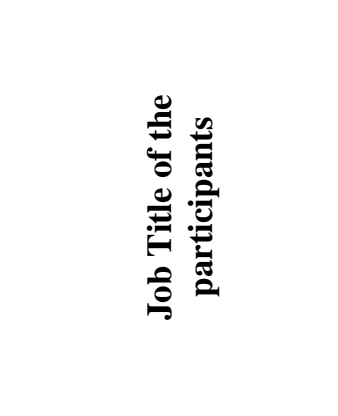 & $\begin{array}{l}\text { - } \text { The sampling unit was Superintendent of Police } \\
\text { - } \quad \text { Deputy Superintendent of Police } \\
\text { - } \quad \text { Ptaff officer to superintendent Police officer } \\
\text { - } \quad \text { Inspectors Sindh Police } \\
\text { - } \\
\text { - } \\
\text { Assistant Sub Inspectors }\end{array}$ \\
\hline Extent & $\begin{array}{l}\text { The extent of the research was District Police Offices of Khairpur, Tando Mohammad Khan } \\
\text { and Sukkur districts. }\end{array}$ \\
\hline Time & The time of the interviews was August \& September 2019. \\
\hline
\end{tabular}

\subsection{Data Collection Instrument}

In this research the author used face to face data collection instrument in depth interviews for investigation of problems of recruitment process challenges. The authors conducted semi-structured interviews for Sindh Police employees of Khairpur, Tando Mohammad Khan, and Sukkur districts. The response was collected based on 05 blocks/themes. The total number of participants were 15 and valid response was 10 out of 15 personnel.

\subsection{Demographics}

This section covered the basic information about the officers who was participating in the interview. Mainly officer designation, experience, and location was recorded. The following Table 2 summarizes the statistics of

Table 2.Interviewee particapennts details

\begin{tabular}{|c|c|c|c|c|c|}
\hline 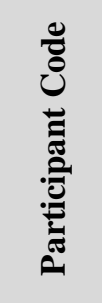 & 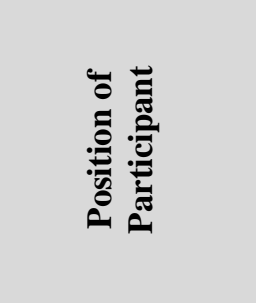 & 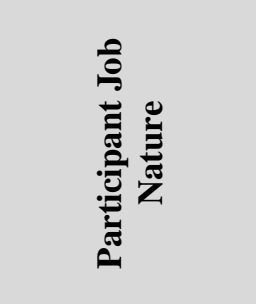 & Participant Job Responsibility & 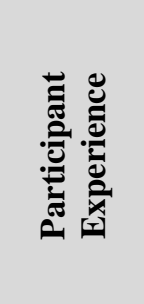 & 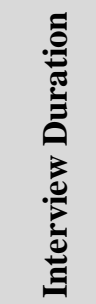 \\
\hline $\begin{array}{c}S P- \\
I P-01\end{array}$ & $\begin{array}{l}\text { Superintendent c } \\
\text { Police }\end{array}$ & Principal $(R T C)$ & $\begin{array}{c}\text { Head of the recruitment training } \\
\text { center, Khairpur }\end{array}$ & 23 years & $\begin{array}{l}45 \\
\text { mints }\end{array}$ \\
\hline $\begin{array}{c}S P- \\
I P-02\end{array}$ & $\begin{array}{c}\text { Staff officer to } \\
\text { SP }\end{array}$ & Management & $\begin{array}{l}\text { Managing the protocols of } \\
\text { superintendent of police, managing } \\
\text { recruitment records of newly } \\
\text { appointed soldiers and officers. }\end{array}$ & 18 year & $\begin{array}{l}40 \\
\text { mints }\end{array}$ \\
\hline
\end{tabular}




\begin{tabular}{|c|c|c|c|c|c|}
\hline $\begin{array}{c}S P- \\
I P-03\end{array}$ & Inspector & IT Wing & $\begin{array}{l}\text { Look after the information } \\
\text { technology related applications and } \\
\text { recruitment training instructor. }\end{array}$ & 07 years & $\begin{array}{l}30 \\
\text { mints }\end{array}$ \\
\hline $\begin{array}{c}S P- \\
I P-04\end{array}$ & Sub Inspector & Office Management & $\begin{array}{c}\text { Managing the necessary } \\
\text { documentation and investigation }\end{array}$ & 14 years & $\begin{array}{c}40 \\
\text { mints }\end{array}$ \\
\hline $\begin{array}{c}S P- \\
I P-05\end{array}$ & Inspector & Office Management & $\begin{array}{c}\text { Responsible of records } \\
\text { management for investigation. }\end{array}$ & 11 years & $\begin{array}{c}30 \\
\text { mints }\end{array}$ \\
\hline $\begin{array}{c}S P- \\
I P-06\end{array}$ & $\begin{array}{l}\text { Assistant Sub } \\
\text { Inspector }\end{array}$ & IT Wing & Managing the official records. & 18 years & $\begin{array}{l}35 \\
\text { mints }\end{array}$ \\
\hline $\begin{array}{c}S P- \\
I P-07\end{array}$ & Inspector & Motor wing & $\begin{array}{c}\text { Managing the recruitment } \\
\text { infrastructure and supporting } \\
\text { technical machinery }\end{array}$ & 30 year & $\begin{array}{l}30 \\
\text { mints }\end{array}$ \\
\hline $\begin{array}{c}S P- \\
I P-08\end{array}$ & $\begin{array}{c}\text { Staff Officer to } \\
\text { SP }\end{array}$ & $\begin{array}{c}\text { Office Management and } \\
\text { protocol }\end{array}$ & $\begin{array}{l}\text { Delivering the technical resources } \\
\text { for recruitment personnel }\end{array}$ & 25 year & $\begin{array}{l}48 \\
\text { mints }\end{array}$ \\
\hline $\begin{array}{c}S P- \\
I P-09\end{array}$ & $\begin{array}{l}\text { Assistant sub } \\
\text { inspector }\end{array}$ & Office Management & $\begin{array}{l}\text { Managing the security of } \\
\text { recruitment system }\end{array}$ & 10 years & $\begin{array}{l}30 \\
\text { mints }\end{array}$ \\
\hline $\begin{array}{c}S P- \\
I P-10\end{array}$ & Inspector & $\begin{array}{l}\text { Office Management and } \\
\text { training instructor }\end{array}$ & $\begin{array}{l}\text { Master trainer, monitoring the } \\
\text { training section of RTC. }\end{array}$ & 11 year & $\begin{array}{l}45 \\
\text { mints }\end{array}$ \\
\hline
\end{tabular}

\subsection{Findings}

The author analysed the interviewee particapents data and finding related research weakness in recruitment process of Sindh Police in Table 3.

Table 3. Summary of weaknesses and recommendations for recruitment process in Sindh Police

\begin{tabular}{|c|c|c|}
\hline Recruitment Steps & Weaknesses & \multicolumn{1}{c|}{ Recommendations } \\
\hline & - The Sindh Police department is & - An efficient optimized central computerized \\
already Information technology & system required for recruitment \& selection \\
department but still not working & smart planning \& development \\
& regarding recruitment Process. & \\
\hline
\end{tabular}




\begin{tabular}{|c|c|c|}
\hline 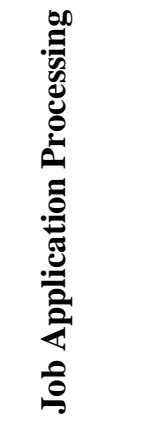 & $\begin{array}{l}\text { - Job application receving is } \\
\text { manual process and department } \\
\text { do not issued unique number of } \\
\text { applicant's application. } \\
\text { - Any other employee of } \\
\text { department or other notable } \\
\text { person can add other applicant } \\
\text { records without necessary } \\
\text { formalities of Sindh Police } \\
\text { department. }\end{array}$ & $\begin{array}{l}\text { - Need to Sindh Police department digital } \\
\text { recruitment system. } \\
\text { - Digital Recruitment model enables the auto } \\
\text { generated number of application records. } \\
\text { - No one can add record of applicant after the } \\
\text { completion of deadline of advertisement. }\end{array}$ \\
\hline 莺 & $\begin{array}{l}\text { - Sindh Police department } \\
\text { recruitment team take too much } \\
\text { time for manual scrutiny list of } \\
\text { pre selection candidates. }\end{array}$ & $\begin{array}{l}\text { - Need to develop the digital recruitment model } \\
\text { for enhancing the recruitment process } \\
\text { primitive criteria. }\end{array}$ \\
\hline 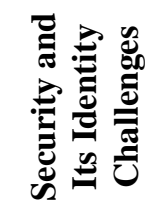 & $\begin{array}{l}\text { During the recruitment process } \\
\text { Sindh Police recruitment team } \\
\text { can not identify that person is } \\
\text { applicable or not. }\end{array}$ & $\begin{array}{l}\text { - Digital Smart system check applicant identity } \\
\text { by using thier biomatrics, system connected } \\
\text { through NADRA and personal data centres . }\end{array}$ \\
\hline
\end{tabular}

\subsection{Recruitment Strategy /Planning:}

In this research author investigated and analysed the interviews data of recruitment strategy of Sindh Police that how Sindh Police create planning documentation for recruitment process these following sub steps covered in recruitment strategy/ planning which is the part of theme 2.

\subsection{Responses of Sindh Police personnel:}

\section{A. SP-IP-01 Said:}

"The competent authorities of Sindh Police department i.e. IG (An Inspector General of Police) approved the sanctioned number of vacant different position in Sindh Police, after that Sindh Police department develops strategic planning for initial recruitment procedure in assign the particular task to Sindh Police Regional Officers (DIGs)"

- Recruitment approval of compitenent authorthy i.e I.G ( Inspector General) Sindh Police

- Plan for announcement of jobs

- Recruitment timeframe for appointment

- Internal/ external necessary requirements for applicant
- Departmental necessary examinations and passing critearea

- Interviews timeframe

- Necessasry medical reports from reputed public sector hospitals

- Security clearance report from concern policing stations.

"Still we are working on manual recruitment system, there is no any such computerized system for recruitment and selection process in Sindh Police which will be cost effective and save the department time".

B. SP-IP-02 Said:

"Whenever Sindh Police department announces vacant jobs, concern department announces the official tenders for publishing the advertisement in different newspapers, which is highly cost paid".

C. SP-IP-07 Said:

"The head of Sindh Police officer approved the required number of vacancies after the proposal acceptance from finance department government of Sindh, after that Sindh Police admin department developed recruitment goals for concern regional officers, these concern officers are Deputy inspector of general (DIG) and district police officers" 


\subsection{Job Application Processing}

In this section briefly explains and examines the interviewee participants given answers that how Sindh Police department invites and collects the jobs applications from maximum number of applicants, what are the necessary requirements for applying any vacant position in law enforcement departments of government of the Pakistan, specially the Sindh Police department necessary requirements of Sindh Police recruitment process, the pre-selection criteria, minimum qualification of applicants, age limit of applicants and domicile criteria for appointment in the Sindh Police department.

\subsection{Responses of Sindh Police personnel:}

\section{A. SP-IP-01 Said:}

"The Sindh Police department invites the candidates by using different media sources such as Electronic media, print media, social media groups and FM radio transmission, these sources are highly expensive as compare computer web-based technologies"

"As per recruitment rules of law enforcement agencies of Pakistan the applicant must be minimum qualification is F.sc (Intermediate) and minimum age is 18 years, maximum age is 28 years for appoint law enforcement agencies of Pakistan, Sindh Police issuance sample format of job application preformat, same manual preformat candidates filled by hand and attached supporting documents and submit it nearest headquarter of district police office.

\section{B. SP-IP-02 Said:}

"Sindh Police department sectioned budget for the recruitment operations and same as sectioned budget for newly appointed personnel of Sindh Police department, this is very huge amount to pay different media sources to publish/ invite the job applications by using graphical intentions"

"After the invitation process of Sindh Police department collects manually job applications at same time in various regional offices of Sindh Police department, applicants apply manually and attached hard copies of relevant documents, most of documents found fake, or found some necessary documents missing, such as most of applicants could not attached updated CNIC copies, which is top most drawback in an existing system".

\section{SP-IP-10 Said:}

"Most of job seekers are belongs to different rural areas of Sindh, due to unemployment, applicants cannot attach their relevant educational documents properly, also most of applicant fill-up job applications preformat by market commercial agents to purchase and fill-up Sindh Police preformat manually, it's also a drawback that most of applicants are computer literate but they also apply by using manual application preformat".

\subsection{Scrutinization of the job applications:}

The scrutiny is the third step of recruitment planning of Sindh Police, this section explains that how Sindh Police scrutiny the job application, what are the necessary requirements of candidates, how candidate can be able for screening test. This section of research analysis gives detailed structure of Sindh Police recruitment policies and how Sindh Police checks the manual necessary requirement along with submitted applications.

\subsection{Responses of Sindh Police personnel:}

\section{A. SP-IP-01 Said:}

"After the completion of job receiving applications during given timeline, the Sindh Police department announce the news alert with different media sources e.g. (print media, electronic media, social media forum and FM radio transmission) for screening of applied number of candidates, this is very cost paid transmission expect social media groups".

"For the basic selection, the candidate must have chest= "33x34", height=" $5 \times 5$ " and running target is $1.6 \mathrm{KM}$ in maximum 07 minutes around the circle, after these necessary requirements candidate meets up then he/she is eligible for further process".

\section{B. SP-IP-03 Said:}

"During the scrutiny process of Sindh Police personnel check the candidate chest, height and other necessary requirement manually, this information can be changed at the any stage of recruitment and selection procedure, but if here is digital system anyone of Sindh Police personnel cannot update or modify the candidate record which is recorded during the scrutiny process".

\section{SP-IP-10 Said:}

"Recruitment and selection record of Sindh Police is also sensitive record because of as per given record of candidate would be select and recruit in the Sindh Police department".

\subsection{Security / Identity Challenges of Applicants:}

This section explains on how Sindh Police identifies the job applicants during the scrutiny process, examines that what are the challenges faced by Sindh Police during the recruitment and selection prodecure, how Sindh Police identifies the real applicant based on manual job application proferma, what are the secruity risks during the of recruitment and selection procedure.

\subsection{Responses of Sindh Police personnel:}

A. SP-IP-01 Said:

"Sindh Police personnel check the identity by manual computerized national identity card during the entrance of recruitment and selection hall, still we don't have any state-of-the art system which will connected with 
NADRA (national database registration authority) and Sindh Police personnel identify the candidate within nanoseconds".

\section{B. SP-IP-02 Said:}

"Security management is a big challenge for Sindh Police department, because of crowd come from different divisions and districts of Sindh, we cannot able to identify that candidate resident (domicile) is real or CNIC given by candidate is same or not".

\section{CONCLUSION}

The purpose of this research project study was to provide the state-of-the art software engineering based developed conceptual model for digital e-recruitment system for Sindh Police by using IoT (Intern of Things) trends, which will be cost effective, less time consumption and transparent record keeping as compare an existing traditional manual recruitment system of Sindh Police department. Traditional recruitment system of Sindh Police department, government of Sindh sued to hire the third party recruitment organization for recruitment operations which is highly cost paid as compare this proposed model of Sindh Police, Sindh Police information technology department extend this suggested model and implement suggested model for transparent recruitment in the Sindh Police, now back in the past years of recruitment and selection of Sindh Police department were placed jobs advertisement in various national newspapers of Pakistan which was huge amount paid to concerned newspapers for published the jobs advertisements commercially, nowadays however the optimized digital recruitment modelwas much more beneficial for the recruitment system. More, it cost effective, faster, transparent, and user friendly compared to old traditional recruitment system of Sindh Police of Pakistan.

\section{REFERENCES}

[1] D. N. Paper, "Problems Facing By Sindh Police During the Transparent Recruitment, 2018. [Online].Available:https://archive.pakistantoday.co m.pk/2018/06/22/former-igp-jamali-others-heldresponsible-for-illegal-recruitment-in-sindh-policereport/. [Accessed: 19-Apr-2021].

[2] U. V Alola and R. Alafeshat, "The impact of human resource practices on employee engagement in the airline industry," $J$. Public Aff., vol. 21, no. 1, p. e2135, 2021.

[3] F. Saleem, "The impact of information specificity in recruitment advertisements on the application pursuit process in Pakistan," African J. Bus. Manag., vol. 4, no. 15, pp. 3315-3320, 2010.
[4] J. Ashraf, "Examining the public sector recruitment and selection, in relation to job analysis in Pakistan," Cogent Soc. Sci., vol. 3, no. 1, p. 1309134, 2017.

[5] M. Mbodila, E. Obeten, and I. Bassey, "Implementation of novel vehicles' traffic monitoring using wireless sensor network in South Africa," in 2015 IEEE International Conference on Communication Software and Networks (ICCSN), 2015, pp. 282-286.

[6] V. V. Anand et al., "A study on effectiveness of recruitment organizational Support in ITES," Int. J. Pure Appl. Math., vol. 119, no. 7, pp. 27552764, 2018.

[7] S. L. Ting, A. H. C. Tsang, and Y. K. Tse, "A framework for the implementation of RFID systems," Int. J. Eng. Bus. Manag., vol. 5, no. Godište 2013, pp. 5-9, 2013.

[8] R. K. Yin, Case study research: Design and methods, vol. 5. Sage, 2009.

[9] P. Y. Khillare and S. K. Shirsale, "A Study of Conceptual Framework of E-Recruitment in Current Business Scenario," Int. J. Res. Manag. Econ., 2017.

[10] S. Greener, Business research methods. BookBoon, 2008. 